\title{
CORRESPONDENCE
}

\section{RILIASE OF STRAIN ENERGY AS A MECHANISM FOR THE MECHANICAL WEATHERING OF GRANULAR ROCK MATERIAL}

SIR, Processes of weathering have been subdivided by many authors into two main groups: mechanical and chemical, with organic agencies falling within both these realms. Both mechanical and chemical factors such as exfoliation, frost heaving, solution etc., which are considered to be possible mechanisms for rock weathering, have one property in common; they act externally upon the rock mass. The character of the rock material itself has only been considered critical in so far as it affects the role that these external processes play in the breakdown of the rock. An important mechanical property of rock material not previously considered for its influence in the process of weathering is, however, the presence of a strain energy stored within the rock as an aftermath of its previous structural history.

Price (1959) considered that a release of strain energy occurs with the formation of joints in any rock material when the rock unit involved is uplifted relative to the level at which strain energy was induced. The mechanism he thus envisaged is very similar to the formation of rock-bursts in deep mines, with the release of confining pressure allowing expansion of previously constricted material in a more or less violent fashion.

In an examination of the mechanism whereby strain energy can be stored in granular rock material Emery (1964) noted that such rocks can be regarded as units of polycrystalline material which are held together by atomic, ionic or molecular bonds acting within them and any cementing material which may be present, and at every interface of contact. On loading this system deformation will occur within both the polycrystalline grains and cement, and along the interfaces between adjacent grains. Different materials which, say, make up the grains will, however, possess different mechanical properties and so will deform at different rates and to different degrees. When the load is released these same differing mechanical properties will therefore result in the instantaneous release of some of the strain energy stored in the deformed grains while the remainder is lost over an increasing period of time, a proportion never being released while the rock still forms a bonded mass. The experiments of Price (1964) clearly demonstrated the validity of this principle for coal measure rocks taken from depth in mines. Emery (1964), however, further recorded the occurrence of rock-bursts of considerable violence in mines at a depth of only $38 \mathrm{~m}$ and considered that substantial strain energies can exist in rocks without relation to their present depth of burial.

The conclusion is thus reached that, with all other factors excluded, rock material consisting of an aggregate of grains held together by some intergranular bond and with a previous history of loading (either hydrostatic or tectonic) can possess high values of strain energy, stored within and between the grains, at ground surface level, and that a proportion of this strain energy will remain permanently stored within the rock mass while it remains a coherent unit. The release of this final, residual strain energy can therefore only be initiated by the weakening of the bond between the grains making up the rock mass.

With the formation of joints in a rock unit a considerable percentage of the primary strain energy, which resulted from its previous loading history, must be released, but not all, as joint fractures are usually discrete and do not pervade the whole rock mass. Thus even in a closely jointed granular rock mass at ground surface some residual strain energy must remain stored within the unit.

At ground surface level, however, various mechanical, chemical and organic factors are present which are absent at deeper levels, conventional processes of weathering acting so as to wcaken the intergranular bonds within the rock mass. These forces are therefore likely to cause the individual grains to separate and become discrete units once more simply by initiating the release of the residual strain energy.

This discussion has, so far, been confined to simple granular materials such as sandstone or conglomerate yet, in point of fact, all igneous, metamorphic and sedimentary rocks, except the glasses, consist of a series of interlocking units, whether these be 
crystallised or fragmentary, which will, unless the units be all of the same composition, crystallography, form, and orientation, store strain energy if subjected to any form of loading. Ease of weathering of any given rock unit in a uniform environment is therefore not only dependent upon the lithology involved but also upon its previous loading history as reflected in the intensity of jointing and residual strain energy level which the rock unit may possess.

It is of interest to note that the product of weathering by release of intergranular strain energy would consist of a loose aggregate of the various grains or crystals which comprised the initial rock mass. Once so released the individual mineralogy of the grains would determine their degree of survival. Such a mechanism of formation is easily applied to many of the weathering products of such widely contrasted rock types as granite and sandstone. The gritstone Edges of Derbyshire and Staffordshire show the production of a loose discretely granular sand the origin of which may be cxplained by a combination of conventional processes of weathering aiding the release of intergranular stresses, while the presence of the decply rotted granite, or growan, over much of Dartmoor may also owe its origin, at least in part, to this mechanism. The occurrence of the growan on Dartmoor separating the upstanding masses of the relatively unaltered tors (Linton 1955) thus leads to the further consideration that perhaps the tors represent zones of low initial strain energy level. This, in turn, would then be reflected in the development of only a widely spaced joint system in these zones when the granite was uplifted to its present position, with little residual strain energy remaining after jointing to facilitate intergranular breakdown. In contrast. the areas of growan would then correspond to zones of high initial strain energy level with the later development of a tight joint system in which a high residual strain energy level remained and aided cven fur ther the breakdown of the internal rock structure.

\title{
REFERENCES
}

IMI:RY,C. L. 1964. Strain Energy in Rocks. p.235. 260 in State of Stress in the Larth is Crust. (Fd. W. R. Judd). Elsevier, New York.

LINTON, D. L. 1955. The problem of tors. Geog. J., 121, 470.486.

PRICE, N. J. 1959. Mechanics of jointing in rocks. Geol. Mag., 96, 149167 1964. A study of time-strain behaviour of coal measure rocks. Int. J. Rock Mech. Min. Sci., 1, $277 \ldots 303$.

\author{
DEPARTMENT OF GEOLOGY, \\ UNIVERSITY OF EXETER, \\ EXETER. \\ 14 th March, 1969.
}

E. M. DURRANCl:

\section{CARBONIFEROUS CONODONTS IN THE SOUTH-WESTERN PENNINES}

SIR, - An investigation, by the author, of conodont faunas in the Lower Carboniferous rocks of the south-western Pennines is at present in progress. This work demonstrates the occurrence of conodont faunas which appear to fill a gap in the succession of conodont assemblage zones proposed by Rhodes, Austin \& Druce (1969). These authors demonstrated that yields of conodonts were very low from the dolomitic limestones of the Upper Caninia $\left(\mathrm{C}_{2}\right)$ Zone of the Avon Gorge sections, near Bristol. They suggested that the low yields might be due either to destruction by secondary dolomitisation or to the existence of an unfavourable depositional environment. More recent investigations by Austin, Conil \& Rhodes (personal communication) suggest that there is also a non-sequence at the base of the Caninia Oolite in the South-Western Province.

The paucity of conodont faunas from the Upper Caninia $\left(C_{2}\right)$ Zone is probably due to unfavourable environment since the writer has found that complete secondary dolomitisation of a limestone band in the Namurian of north Staffordshire has had no appreciable effect on the micro-structure of a large and very varied conodont fauna. 